\title{
An Introduction to Modern Political Theory
}


By the same author

Hayek's Social and Economic Philosophy

On Classical Liberalism and Libertarianism

The New Right

Welfare

The Morality of Business Enterprise 


\section{An Introduction to Modern Political Theory Third Edition}

\section{Norman P. Barry}

Professor of Politics

University of Buckingham

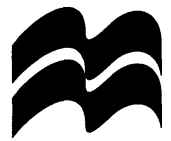


(C) Norman P. Barry 1981, 1989, 1995

All rights reserved. No reproduction, copy or transmission of this publication may be made without written permission.

No paragraph of this publication may be reproduced, copied or transmitted save with written permission or in accordance with the provisions of the Copyright, Designs and Patents Act 1988, or under the terms of any licence permitting limited copying issued by the Copyright Licensing Agency, 90 Tottenham Court Road, London W1P 9HE.

Any person who does any unauthorised act in relation to this publication may be liable to criminal prosecution and civil claims for damages.

First edition 1981

Reprinted 1982, 1983, 1984, 1985, 1987

Second edition 1989

Reprinted 1990, 1992, 1994

Third edition 1995

Published by

THE MACMILLAN PRESS LTD

Houndmills, Basingstoke, Hampshire RG21 2XS

and London

Companies and representatives

throughout the world

ISBN 978-0-333-61682-6

ISBN 978-1-349-24104-0 (eBook)

DOI 10.1007/978-1-349-24104-0

A catalogue record for this book is available from the British Library.

$\begin{array}{rrrrrrrr}10 & 9 & 8 & 7 & 6 & 5 & 4 & 3 \\ 04 & 03 & 02 & 01 & 00 & 99 & 98 & \end{array}$

Copy-edited and typeset by Povey-Edmondson

Okehampton and Rochdale, England 


\section{Contents}

Preface to the First Edition

viii

Preface to the Second Edition xii

Preface to the Third Edition xiv

Glossary $\quad \mathrm{xv}$

I RULES AND ORDER 1

1 Philosophy, Social Science and Political Theory 3

1 The current state of political theory 3

2 Language 7

3 Liberalism 15

4 The decline of Marxism and the rise of communitarianism 24

2 Law and Social Control $\quad 30$

1 Law and social philosophy 30

2 Natural law 33

3 Law as command $\quad 37$

4 Legal realism 45

5 Legal systems as systems of rules $\quad 47$

6 Principles, rules and the law 51

7 Law and society 54

8 The rule of law $\quad 56$

3 The State $\quad 61$

1 The state in political philosophy 61

2 Analysis of the state 66

3 The economic theory of the state 70

4 The organic theory of the state 79

5 Anarchism $\quad 82$

4 Authority and Power $\quad 86$

1 Authority, power and coercion $\quad 86$

2 The nature of authority $\quad 94$

3 Some problems with power 102 
4 Social theories of power 107

II VALUES 113

5 Political Principles $\quad 115$

1 Political principles and political philosophy 115

2 Logical positivism and emotivism 116

3 Universalisability and ethical pluralism 119

4 Contractarianism 123

5 Utilitarianism 126

6 Individualism 135

7 Marxism and collectivism 140

8 Feminism 143

6 Justice 148

1 The problem of justice 148

2 The meaning of justice 152

3 Procedural justice 158

4 Social justice 167

5 Rawls's theory of justice 173

7 Equality 184

1 The equality principle 184

2 Human nature and equality 186

3 Equality of opportunity 189

4 Equality, markets and resources 194

5 Equality, the family and feminism 200

8 Liberty 204

1 Liberty in political philosophy 204

2 The meaning of liberty 206

3 Negative and positive liberty 216

4 Liberty as autonomy 221

5 John Stuart Mill and the value of liberty 225

6 Law, morality and paternalism 232

9 Human Rights $\quad 236$

1 Rights in political theory 236

2 Analysis of rights 239

3 Critics of rights 248

4 Human rights, economic and social rights and welfare 253 
10 The Public Interest and Democracy 260

1 The public interest 260

2 Democracy 270

3 Procedural democracy and the public interest 281

4 The radical critique of liberal democracy 292

$\begin{array}{ll}\text { Notes } & 298\end{array}$

Bibliography $\quad 304$

Name Index $\quad 314$

Subject Index 317 


\section{Preface to the First Edition}

This is a general book on contemporary social and political theory, designed to introduce the reader to the kinds of problems political theorists deal with and to some of the answers that have been suggested. There is very little in it that is original, but originality has not been the aim of this author. Rather, the intention has been to present in a coherent form a growing body of knowledge which will provide the student with a foundation on which he (or she) can build by consulting more advanced work in the specialist journals.

Yet even this modest task requires some explanation, if not justification. The writing of a general book on social and political theory is likely to be provocative for at least two reasons. First, the necessarily controversial nature of the subject matter, and secondly, the absence of any real agreement as to what the subject is about. The first of these reasons seems to me trivial. The fact that the concepts analysed in this book are used in political argument does not mean that rational, dispassionate analysis is impossible; in fact, it makes the need for such an approach all the more pressing. The second reason is a little more disturbing since it is true that political theory, when it is not just history of political thought, is taught in a great variety of ways in university social science departments. Nevertheless, I feel that the kinds of topic dealt with in this book are of primary importance to political theory courses, even though the manner of treating them will no doubt meet with some opposition.

The major justification for a book of this kind, however, is the enormous increase in the volume of literature in social and political theory that has occurred in the last ten years. Twenty years ago there was little more than a handful of books and articles of importance in a subject area which was thought to be infertile. This of course reflected the dominance of linguistic philosophy and 'empirical' political science, and both those disciplines eschewed the substantive normative questions that had traditionally been the concern of social and political theory. Even the use of the term 'theory' was questioned here since scientifically-minded political scientists (and philosophers) objected to an activity being described as 'theoretical' which did not concern itself with producing theories with empirical content, and which could not generate hypotheses that could be 'tested'. However, 
the kind of linguistic analysis that once threatened to banish political philosophy from the field no longer monopolises the subject and the empirically-biased political scientists have not been conspicuously successful in the production of general theories. Curiously enough, the most successful theories in politics that have appeared in recent decades have not come from the behaviouralists at all (and indeed they can hardly be called empirical) but from economics. They also have a clear relevance to some traditional concerns of political theory. This is especially true of the theory of democracy (see Chapter 10).

The major contributions to contemporary political theory have come from a number of academic disciplines - mainly law, economics and philosophy - so that the subject retains the heterogeneous nature it has always had. It is this that makes the subject difficult for the beginner and a major purpose of this book is to present some important ideas that have emerged from these disciplines in such a way as to make them relevant to the interests of students of politics.

Nevertheless, the book is not designed for beginners in political studies but for second-year (or third-year) students of politics who have already done some history of political thought and introductory courses in other social science subjects. It is for this reason that I have not filled the text with long quotations from the 'classics' of political theory but concentrated mainly on getting some contemporary and less familiar ideas across. Although the standard topics in the subject are covered I have included consideration of some less familiar ones and left out one or two traditional subjects. Of the latter my omission of a sustained discussion of political obligation requires some explanation. Although some important books and articles have appeared on this subject in recent years, and it has been assumed important in the practical world of politics, I say little about it because it illustrates much less well than other concepts the special contributions law, philosophy and economics make to political studies. The question of whether one ought to obey the state seems to give rise to the type of answer which does not involve the kind of rational argument that is characteristic of the questions of justice, income distribution, the public interest and procedural democracy. In other words, the problem of political obligation involves a subjective, personal judgement in a way that other topics do not.

Despite the above comments the book could be tackled by readers with very little knowledge of the subject area. No knowledge is assumed and while the complete beginner might find the first two chapters a little difficult, the going does get easier. It is important, 
however, that the early chapters be properly absorbed since ideas discussed there reappear throughout the book. Concepts explained in the early stages are employed in a variety of contexts.

The book is divided into two parts, one dealing with the conceptual problems involved in the explanation of social institutions such as rules, law and state, and the other with the traditional political and moral 'values', such as justice, equality, freedom and rights. This is for convenience only and the author would be the first person to insist that there is an obvious connection between, say, statements about law and statements about justice and equality. Any arbitrariness in the presentation of the topics, then, is the consequence of an attempt to find a way of introducing certain concepts to students in a manageable form.

There is one feature of the book which is perhaps more difficult to explain away. It is written from a certain point of view, which may be called 'liberal-rationalist'. This is an intellectual rather than a political standpoint and I do not use the word liberal in a party political sense at all (nor in the sense in which it is typically used in American politics). The liberal-rationalist approach assumes that many political problems, at least in reasonably stable societies, are capable of being resolved by analytical methods, so that political discord is not always the clash of irreconcilable values but often represents a failure to explore properly the relationship between principles and policies. Also, the liberalrationalist claims some objectivity in that his main concern is to examine the consequences of holding certain principles rather than to advance party or class interests. Thus liberals find themselves 'leftwing' on some issues and 'right-wing' on others. Of course, they would reject such labels anyway as being severe hindrances to a proper analytical approach to political problems.

While I follow this approach throughout the book I have contrasted it with other approaches so that someone unsympathetic to liberalrationalism would, I hope, still find the book of some use. In fact, the analytical problems in Part One do not involve the kind of value questions that appear in Part Two and should be of interest to all students of social philosophy, whatever their political views. A further justification for my approach is that many of the innovations in the subject in recent years have come from writers in this tradition.

As on a former occasion, I am grateful to Barbara Abbott for her excellent work in typing the bulk of the manuscript; and to Margaret Sheridan for help in the final stages. 
I am indebted to my colleague John Cunliffe. He read the entire typescript with great care and made many extremely helpful suggestions, most of which have been incorporated into the text. The errors that remain therefore are entirely of my own making and, regrettably, I must take the final responsibility for them.

Birmingham, England

October 1979 


\section{Preface to the Second Edition}

Since its first publication in 1981 this book has enjoyed, to the surprise of its author, some considerable success. As a student's 'text' the book was perhaps a little unusual in that it was written from the standpoint of 'liberal individualism' or 'liberal-rationalism'. In this much expanded edition this intellectual position is retained, though I think my approach is a little more critical. Ironically, since the book's first publication the world of political theory has become much more receptive to this approach. Nevertheless, there is no attempt to present liberal individualism here as if it were the conventional wisdom in political thought.

Although the major alternative, in methodological terms at least, to liberal individualism is collectivism this latter view is by no means confined to socialism. In the past decade there has been a resurgence of a certain kind of 'communitarianism' in political theory; a style of political theory that rejects the abstract individualism and indeed universalism, of much liberal thought, and puts political argument in the context of particular social forms and institutional arrangements. I have tried to take account of this style of politics at certain key stages of the book. It should be clear to the reader that these approaches have no counterparts, either overt or covert, in the 'real' world of party politics; they are simply differing ways of understanding the concepts and arguments that are used in that world.

Although the format of the book has remained unaltered, with only minor changes to the sub-headings of the chapters, large parts have been completely re-written. The most extensive revisions have been to Chapters 2, 3, 4 and 5 but there are significant alterations to all the others. In the chapter on the state I have paid more attention to public good theory and the problem of the 'Prisoner's Dilemma'; in the chapter on power and authority I have tried to show the relevance of the theory that all political concepts are 'essentially contested' (a doctrine largely absent from the first edition and explained in detail in Chapter 1 of this edition); in the chapter on moral and political principles I have included a special section on contractarianism and eliminated 'economic liberalism' as a separate category.

In the seven years since this book was first published there has been a rapid expansion, in book and article form, of political and social 
philosophy. It would be impossible, even confusing, to give an account of even a fraction of these publications. What I have tried to do, however, is to give some indication of the way that the subject is developing.

Over the years I have benefitted greatly from discussions and arguments with political theorists too numerous to mention by name. However, I would like to express my gratitude to my friend John Gray for his expert knowledge and advice on all aspects of political philosophy, ethics and political economy.

As one of the dwindling band of academics who refuses to come to terms with that emblem of office modernity, the word-processor, I remain forever dependent on expert secretarial assistance. This time, I managed to persuade a whole team of highly competent secretaries that political theory really is more important than their families and peace of mind. I am grateful to Elizabeth Stewart, Angela Brown, Anne Longbottom and Sandra Gilbert for typing the manuscript so expeditiously. 


\section{Preface to the Third Edition}

The third edition of this book retains the chapter structure of the first two editions and broadly covers the same issues and themes. Every chapter has been altered in some way or other and new material has been added to improve the coverage of the field and, in particular, new developments. The introductory chapter and those on justice and equality have been substantially rewritten. It is impossible to cover all the vast literature that is continually being produced but I have tried to indicate the main lines of argument. Overall, I do not think that the fundamental points of dispute have changed significantly. I have, however, included a more detailed consideration of communitarianism than hitherto. The theoretical disagreement between this approach and the various forms of liberalism has come to dominate the subject in the last twenty years and, although no attempt to resolve the issue is made here, I hope I have indicated to the newcomer to the subject what the argument is about. In the first edition I talked almost exclusively of 'liberal-rationalism' by which I meant that brand of liberalism associated with market economics. In this edition I also discuss in some detail conventional liberal egalitarianism. I hope it is clear which version of this somewhat confusing political doctrine is being addressed. I have incorporated, for the first time, some discussion of feminism. I regret that my consideration is brief and superficial, but space prevented me from a more detailed and thorough analysis.

For the preparation of this edition I am once again indebted to my secretary, Mrs Anne Miller. I would also like to thank Mrs Elizabeth Stewart, as well as Ms Spring McCollum, for their assistance in the final stages. August 1994 


\section{Glossary}

Below are listed the meanings of various terms used in the text. It should be made clear at the outset that no attempt is being made to give exact definitions of these terms. All that is being conveyed is an indication of the way the words are used in the political analysis and argument that appear in the book.

Anthropomorphism. The attribution of human properties to inanimate things. 'Society' is frequently treated anthropomorphically, as if it were capable of being praised or blamed in the way that humans are. A crude example is the phrase, 'it is all society's fault'.

Autonomy. In moral philosophy, the capacity in individuals for making judgements uninfluenced by any considerations other than principle. Almost always opposed to external authority. In social philosophy it requires redistribution of resources so that people's decisions are not the result of adverse economic circumstances.

Behaviouralism. A form of social explanation in which observed behaviour is stressed rather than the simple description of institutions. In behavioural political science formal political institutions are dissolved into 'systems' and 'processes'. It is distinct from behaviourism in that it is not a psychological theory about individual behaviour but involves sociological statements about collectivities.

Behaviourism. The psychological doctrine which holds that the only basis for the study of human behaviour is observable behaviour. Therefore all statements about mental phenomena, such as motives and intentions, are irrelevant because they depend upon introspective knowledge which cannot be verified by experimental methods.

Collectivism. The methodological doctrine that collective terms such as 'state', 'society' and 'class' stand for entities which have a real existence over and above that of individuals. Collectivists argue that theories of social phenomena cast solely in terms of individual action fail to capture the significance of general social factors in the determination of events. 
Communitarianism. The doctrine that presupposes that the identity of individuals can only be established by reference to pre-existing social forms. Objective moral standards are determined by an exploration of the meanings of these forms. Opposed to abstract individualism.

Deduction. The form of reasoning in which the conclusion of an argument necessarily follows from the premises. The validity of a deductive argument is established if it is impossible to assert the premises and deny the conclusion without self-contradiction. In the social sciences only economic theory makes extensive use of the deductive method.

Deontology. The ethical theory that holds that certain moral duties are absolutely binding irrespective of consequences. Normally it emphasises the importance of strict compliance with moral rules to the exclusion of a consideration of the benefits which adherence to the rules may or may not bring about.

Empiricism. The epistemological doctrine that the only foundation for knowledge, apart from mathematical and logical relationships, is experience. It is contrasted with the various forms of rationalism, all of which maintain that the mind is already equipped with the conceptual apparatus which enables us to understand the external world. In the social sciences empiricists reject a priori reasoning about man and society in favour of factual and statistical enquiries. See also behaviourism and positivism.

Epistemology. The theory of knowledge. The major questions of epistemology concern the nature of our knowledge of the external world, the source of knowledge and how claims to knowledge can be substantiated.

Essentialism. The doctrine that the key to the understanding of social phenomena lies in discerning the true nature or essence of things which lies behind their external manifestations. In Plato's theory of the state, for example, it is argued that existing state organisations are pale reflections of an underlying essence or form of the state, knowledge of which is acquired by philosophical reflection.

Historical materialism. The Marxist doctrine that the factors determining historical development are ultimately economic. Changes 
in the 'superstructure' of society, that is the state organisation, law, religion and morality, are a function of changes in the substructure, that is, the economic mode of production. The doctrine is especially directed at those theories that emphasise the independent influence of ideas in the determination of historical change.

Historicism. The doctrine, mainly but by no means exclusively associated with Marxism, that the study of history reveals trends or patterns, of a law-like kind, from which it is possible to predict future economic and social structures and historical events. Historicist 'laws' are of a quasi-empirical kind in that they are based on supposedly observable regularities and are therefore different from the laws of conventional economics which are ahistorical deductions from axioms of human nature.

Individualism. The methodological doctrine, associated with Popper and Hayek, that collective words such as 'state' or 'society' do not stand for real entities. The behaviour of collectivities can only be understood in terms of individual motivations and volitions.

Induction. The method of reasoning by which general statements are derived from the observation of particular facts. Therefore inductive arguments are always probabilistic, in contrast to deductive arguments. Induction was thought to characterise physical science in that laws were established by the constant confirmation of observed regularities. However, since no amount of observations can establish a general law (the most firmly established regularity may be refuted in the future) the generalities established by science seemed to rest on insecure, if not irrational, foundations. Popper argued that, while theories cannot logically be established by repeated confirmations, they may be falsified.

Metaphysical. A metaphysical proposition is one which cannot be tested by normal empirical methods. Logical Positivists thought that a statement which was neither tautological nor empirically verifiable was metaphysical and hence meaningless. Metaphysical statements are not normally thought to be meaningless by contemporary philosophers.

Nominalism. The theory of language that accounts for the meaning of general words not in terms of some universal entity they represent, but as labels to attach to things that share a common property. 
Nominalism is the approach to language adopted by the empirical sciences.

Nomothetic. A nomothetic law is a statement of regularity which holds universally irrespective of time or circumstance. It is a statement of causality from which predictions about future events can be derived. In the social sciences only economic theory can claim to have produced nomothetic laws.

Normative. Normative statements set standards and prescribe forms of conduct; they do not describe facts or events. Although they are frequently used in connection with moral standards, this is not always the case. Legal rules are technically normative in that they make certain forms of conduct obligatory, but they are not necessarily moral. Normative statements typically involve the use of words such as 'ought', 'should' and 'must'.

Persuasive definition. A definition of a word which is designed not to explicate its meaning but to excite favourable (or unfavourable) attitudes. Persuasive definitions of the state, for example, do not convey information about existing states, but aim at provoking approval (or disapproval) of it.

Positivism. This has two meanings. First, a positivist believes in the clear separation of fact and value and argues that theoretical and descriptive accounts of man and society can be made which do not involve evaluative judgements. For example, in jurisprudence a positive lawyer maintains that law must be separated from morals so that a rule is assessed for legal validity, not by reference to its content but to certain objective, non-moral criteria. In the second and more extreme sense, it is the theory that only phenomena which are in principle capable of being observed are of any significance for social science. See also empiricism and behaviourism.

Sociology of knowledge. The attempt to explain the social origins of beliefs that people hold. It is also used by some Marxists to mean that all knowledge in the social sciences is relative to the particular class position of those who profess it, so that there cannot be objective knowledge of society. 
Teleology. A doctrine that explains the nature of things in terms of the ends or purposes they are supposed to being about. In teleological ethics, moral action is evaluated in accordance with how far it brings about a desirable state of affairs. For example, utilitarian ethics evaluates actions in terms of their contribution to the general happiness. 